\title{
EKONOMIA A PERSONALIZM SYSTEMOWY ${ }^{2}$
}

\author{
Economy and personalist system
}

Streszczenie: Celem artykułu jest ustalenie korzyści jakie wnosi związek ekonomii z personalizmem. W artykule wykazano, że liberalizm, neoliberalizm traca sitę oddziatywania. Podkreślono, że z tego kryzysu może wyprowadzić wspótczesne społeczeństwa personalizm systemowy.

Słowa kluczowe: personalizm systemowy, ekonomia, człowiek, społeczeństwo, polityka Abstract: The aim of the article is to determine the benefits of the relationship between economics and personalism. The article shows that liberalism and neoliberalism are losing their impact. It was emphasized that systemic personalism can lead out of this crisis.

Keywords: personalism system, economy, man, society, politics

\section{Wstęp}

Czasy, w których żyjemy, wydają się całkowicie wykluczać połączenie racjonalizmu z etyką w ekonomii. Nie musi być jednak tak dalej. Teoria ekonomii, funkcjonowanie i ustrój gospodarki potrzebują wewnętrznej

1 Prof. zw. dr hab. Stanisław Wójcik, Katolicki Uniwersytet Jana Pawła II w Lublinie, e-mail: wojcikst@kul.pl, ORCID: 0000-0002-5572-3199

2 Niniejszy artykuł jest oparty na wynikach badań własnych nad ekonomią społeczną uzyskanych w latach 1989-2005 oraz personalizmem społeczno-politycznym od $2006 \mathrm{r}$. (Wójcik 1995; 2002; 2015; 2018a; 2020). Personalizm systemowy to nurt filozofii społecznej, koncepcja rzeczywistości, w której działa aktywny i odpowiedzialny człowiek. W Polsce tezy personalizmu uniwersalistycznego, systemowego rozwijał Czesław S. Bartnik. Por. Bartnik 2000. 
racjonalności i uporządkowania, dobrej organizacji rynku, produkcji, wymiany, podziału, reguł wyznaczanych przez teorię, według której wszystko się urzeczywistnia, oraz prawa, które jest wspólne dla wszystkich, zawierając w sobie racjonalność i inteligencję. To błyskotliwa argumentacja odznaczająca się wewnętrzną spójnością, sensem wypowiedzi. Ale ekonomia, podobnie jak prawo i polityka, potrzebuje pilnie również ethosu, tego nośnika wartości, które wprowadzają ład w stosunki międzyludzkie, ludzką komunikację i mimo że obecnie jest tak bardzo niedoceniany, wpływa na procesy gospodarcze oraz na obiektywną teorię. Logos i etyka stanowią zakorzenioną w społeczeństwie całość. Sama pogoń za zyskiem, dążenie do jego racjonalności, maksymalizacji nie może być głównym celem ekonomii. Musi mieć ona także na względzie godność człowieka i społeczeństwa. Drogę do pogodzenia obu celów najlepiej ukazuje personalizm systemowy.

Dzisiaj mamy do czynienia z wieloma doktrynami ekonomicznymi, ale nie dają one satysfakcjonujących wyjaśnień, jak te cele łączyć. Ponadto wszechobecna staje się dezinformacja w ekonomii, to jest celowo błędne interpretowanie rzeczywistości, m.in. wyjaśnienie i prognozowanie zjawisk według teorii zwrotności. Uciążliwa jest jeszcze pełzająca biurokratyzacja gospodarki, która do niedawna (2016 r.) wręcz ją ubezwłasnowolniała. Tłamsiła ją, nękała zwłaszcza małe firmy, a nawet urzędnicy mogli jedną decyzją zdecydować o czyimś bankructwie. Nie ma zgody, co powinno być celem gospodarki: pełna wolność, zamożność, równość, sprawiedliwość, szczęście obywateli. Różnimy się w ocenie, jak osiągnąć pożądany wysoki stan jakości życia, jak poprawić moralną kondycję społeczeństwa i człowieka, status prawa, stabilność instytucji, jak pogodzić bogactwo jednych z godziwą opieką dla innych, zarabianie, a nie życie, staje się głównym sensem istnienia. Ale nie można też zapomnieć o konieczności naprawienia największych krzywd transformacji zarówno tej pierwszej - po 1945 r., jak i obecnej. Szczególnie chodzi o polską wieś i o Polskę lokalną (powiatową). Przemiany te każdorazowo tworzyły silne napięcia gospodarcze, polityczne, społeczne. Mieszkańcy wsi za każdym razem doznawali wstrząsów większych niż miasto. Dlatego dziś trzeba społecznościom lokalnym oddać sprawiedliwość, bo w obu okresach były ostoją życia narodowego i sytuacji politycznej oraz gospodarczej kraju.

Obecnie wiemy lepiej, że jakość naszego życia zależy od prawidłowo określonej relacji człowiek-społeczeństwo w ramach istniejącego kontekstu gospodarczego, prawno-politycznego, moralnego, religijnego. 
Teoretycy ekonomii nie podejmują poważniejszej debaty nad właściwościami i możliwościami człowieka jako osoby posiadającej wiedzę, kompetencje, autorytet - godność. Na potrzebę określenia pożądanej relacji zwraca uwagę katolicka nauka społeczna, ale jej wpływ okazuje się nikły. Także personalizm antropologiczny słabo włącza się do dyskursu ekonomistów. Więcej wnieśli ekonomiści społecznej gospodarki rynkowej i szkoły ordoliberalizmu, ale zbyt jednostronnie podporządkowali jednostkę społeczeństwu, chcąc podkreślić swoje odrębne, polemiczne stanowisko wobec ekonomii klasycznej. Uważam, że dopiero „spotkanie" ekonomii z personalizmem systemowym może nadać nowy impuls rozwojowy ekonomii, ukazując pełniej miejsce człowieka-osoby w życiu ekonomiczno-społecznym. Dominujący nurt klasycznej ekonomii ukształtował przekonanie, że człowiek w sferze gospodarczej działa racjonalnie i zgodnie z własnym interesem. W niewielkim tylko stopniu myślenie takie burzyły początkowo rzadkie, a obecnie coraz częstsze, potężne kryzysy gospodarcze, finansowe, że ten człowiek „homo economicus” nie radzi sobie zupełnie $\mathrm{z}$ ich nieprzewidywalnością, złożonością, a nawet irracjonalizmem procesów gospodarczych, że mechanizm wolnorynkowy zacina się, staje się bezradny. Z tych powodów część ekonomistów, polityków, myślicieli społecznych niegodzących się „by było jak było” rozpoczyna w każdym czasie poszukiwania dookreślenia możliwości i cech człowieka gospodarującego (przez długi czas w teorii ekonomii był on traktowany jako czwarty czynnik produkcji) oraz roli i znaczenia społeczeństwa, jak i przeprowadzenia niezbędnych reform instytucji państwa i prawa, podkreśla znaczenie historii, moralności i religii. Dobry kierunek analizy rzeczywistości gospodarczo-społecznej i działającego w niej człowieka zaczęła wyznaczać europejska, zwłaszcza niemiecka, a także w początkowym okresie polska doktryna społecznej gospodarki rynkowej.

W artykule zarysowano możliwości i rosnące znaczenie personalizmu systemowego, który ukazuje nową perspektywę dla człowieka-osoby w sferze ekonomiczno-społecznej. Tezy są następujące: mamy do czynienia z kryzysem myśli ekonomicznej; gospodarka rynkowa nie może być oderwana od kluczowych wartości: podmiotowości obywatelskiej, realizującej się w jedności ze społeczeństwem zorganizowanym prawnie i instytucjonalnie, stawiającym na realizację dobra wspólnego, ponieważ tak ją zbudowano; dzisiaj u podstaw gospodarki rynkowej jest słaba warstwa chrześcijańska, szerokie uznanie zdobył liberalizm, który niesie pewne wartości, ale też jest postrzegany jako wielkie zagrożenie; utrzymuje się 
konflikt interesów i postaw przedsiębiorców oraz pracobiorców, a także niski poziom moralny i prawny administracji publicznej. $Z$ tego kryzysu antropologicznego może wyprowadzić personalizm systemowy, który wzywa do przywrócenia godności osobie ludzkiej, a także tworzy cały system rzeczywistości, który wszystko koreluje z fenomenem osoby jednostkowej.

\section{Społeczny czy indywidualny wymiar ekonomii}

Polscy prekursorzy myśli społeczno-ekonomicznej: Stanisław Staszic, Hugo Kołłątaj zaczęli rozwijać ten nurt myślenia ekonomicznego, przyznając historii, a także polityce pierwszoplanowe miejsce w swych dociekaniach (Wójcik 2002: 20-21). Oni pierwsi zauważyli, że ekonomii nie można zrozumieć lepiej niż w ramach kontekstu historyczno-politycznego, realiów życia społecznego. Następcy: Fryderyk Skarbek, Józef Supiński, a także przedstawiciele tworzących się w Europie nowych szkół ekonomicznych: historycznej, psychologicznej, a nawet wewnątrz klasycznej dostrzegając słabości rozwijającej się prężnie, ale chaotycznie, klasycznej ekonomii, zgłaszają pod jej adresem uwagi krytyczne do metodologii, do tendencji zawężania zjawisk gospodarczych, izolowania ich od reszty procesu społecznego, wyodrębniania człowieka ekonomicznego od społeczeństwa, formułowania uniwersalistycznych praw opartych na abstrakcyjnej dedukcji zmierzających w kierunku czystej teorii ekonomii (Wójcik 2002: 22 i n.).

Z badań nad polską i europejską myślą ekonomiczną wynika, że rozwijający się nurt ekonomii społecznej pozbawia się z czasem balastu skrajnego historyzmu oraz odrzuca skrajny psychologizm i dialektyczny marksizm. Proponuje jednak ujęcie ekonomii, której rdzeń teoretyczny (klasycznej ekonomii) stara się wzbogacić elementami socjologii, psychologii i katolickiej nauki społecznej. Tendencja ta przybiera postać reprezentowaną dzisiaj przez niemiecką Soziale Marktwirtschaft ${ }^{3}$. W powstającym systemie ekonomii społecznej jest formowany i pogłębiany

3 Ten nurt w ekonomii rozwinęli m.in. Alfred Müller-Armack, Walter Eucken, Wilhelm Röpke, Ludwig Erhard, Konrad Adenauer, a w USA rozwija się Society of Social Economics. 
pogląd, że społeczeństwo jest zbiorowością jednolitą, w którym gospodarują nie poszczególne jednostki czy grupy, których działanie łączy i organizuje wolnorynkowy mechanizm funkcjonujący spontanicznie i w sposób niekontrolowany społecznie, ale całe społeczeństwo. Normuje ono swoją działalność w sposób zorganizowany i z punktu widzenia realizacji wspólnych, społecznych celów, pojęć i zasad. Gospodarstwa indywidualne traktowane są jako części składowe gospodarstwa społecznego, zależne w swoim powstaniu i całej swej działalności od organizacji gospodarstwa społecznego na danym etapie jego rozwoju. Bezpośrednim celem poszczególnych gospodarstw nie jest zaspokojenie własnej potrzeby, lecz wykonanie pracy, wytworzenie dobra zdolnego do wymiany, mającego wartość dla społeczeństwa. Dopiero dalszym celem, przyczyną podjęcia działalności gospodarczej, było zaspokojenie potrzeb osobistych. Typowym gospodarstwem społecznym jest gospodarstwo zarobkowe, świadczące usługi społeczeństwu, uczestniczące w wymianie społecznej. Konsumpcja osobista schodzi na dalszy plan jako owoc pracy społecznej zależny od organizacji, wymiany i twórczego życia społeczno-gospodarczego. Dostrzegam w tym ujęciu zarys teorii "społeczeństwa gospodarującego", które na przestrzeni dziejów zawsze gospodarowało jako całość, mając wytworzone na danym etapie swego rozwoju własne ograniczenia, reguły działania i wzrostu. To typowe stanowisko monizmu społecznego różni je od ujęcia marksistów uważających, że społeczeństwa przedsocjalistyczne były organizmami, w których gospodarowały jednostki bądź grupy, ale nie całe społeczeństwo, oraz od koncepcji liberalnej i neoliberalnej gospodarujących jednostek. Sądzę, że ma ono swoją przyszłość, a jednocześnie dzisiejsi liberałowie polscy przeliczą się, że w UE nie będzie już zintegrowanego społeczeństwa polskiego, a tym samym będą mogli służyć jedynie własnemu egoizmowi (Wójcik 2002: 197-198) ${ }^{4}$.

Teoretycy tego nurtu opowiadają się coraz bardziej zdecydowanie za społecznym, a nie indywidualnym charakterem nauki ekonomii. Jednostkę gospodarującą rozpatrują jako podmiot, ale ukształtowany przez społeczeństwo, któremu podlega. Przekonują o znaczeniu socjologicznego, psychologicznego, prawnego zgodnego z rzeczywistością tłumaczenia zachowań gospodarczych (Wójcik 2002: 198-199). Dobrą ilustrację stanowi proces decyzyjny, w którym realizm i interesy jednostek są

4 Szerzej Kornai 1977; Beksiak 1976. 
determinowane $\mathrm{w}$ sferze realizacji poprzez obowiązujący system pojęć, norm, instytucji. Społeczne rozumienie ekonomii oznacza, że zjawiska gospodarcze nie stanowią izolowanych procesów, lecz są podporządkowane innym dziedzinom działalności społecznej. Stąd formułowanie praw społeczno-gospodarczych opiera się na postępowaniu sięgającym również do źródeł funkcjonowania gospodarki, do zjawisk kulturowych, moralnych, religijnych oraz prawno-politycznych, za którymi stoją siły społeczne pełniące kluczową rolę w rozwoju jednostki i społeczeństwa (Wójcik 2002: 198-199).

Ekonomia społeczna dąży do poszerzenia istniejącej bazy metodologicznej, sięga do nauk społecznych, prawnych, szczególnie do socjologii, do psychologii, przyczyniając się do osiągnięcia nowych perspektyw rozwojowych. Na gruncie ekonomii społecznej uważa się, że tradycyjna ekonomika (teoria klasyczna) nie obejmuje całej rzeczywistości gospodarczej, trzyma się zbyt rygorystycznie swych założeń metodologicznych, że potrzebny jest rozwój badań empirycznych. Podkreśla się tu znaczenie analizy historycznej, socjologicznej, psychologicznej, prawnej i opartej na nich teorii w celu pełniejszego zbliżenia się do prawdy. Ekonomiści społeczni postulują, aby motyw czysto gospodarczy (racjonalne dążenie do maksimum zysku, użyteczności) uzupełnić rozbudowaną systematyzacją czynników zbieżnych, rozbieżnych i pozagospodarczych w relacji do zasadniczego czynnika czysto gospodarczego. W pluralizmie metodologicznym i sięganiu w tym celu do nowych dyscyplin oceniałbym ich usiłowania jako mające na celu przełamanie konserwatywnej tendencji zamykania się w ciasnych ramach wąskiej specjalności (Wójcik 2002: 198-199; szerzej 1995: 124-138).

Przedstawiciele tego nurtu w Europie: Vilfredo Pareto, Max Weber, część niemieckich ekonomistów, János Kornai, a z polskich ekonomistów zwłaszcza Stanisław i Władysław Grabscy, Roman Rybarski, a współcześnie Czesław Strzeszewski, Janusz Beksiak dostrzegali ograniczoność tzw. ścisłej ekonomii i brak perspektyw, wręcz nierealność nauki opartej tylko na modelu wyizolowanej jednostki. Podkreślali oni złożoność zjawisk gospodarczych, które są niewytłumaczalne w świetle klasycznej ekonomii (Wójcik 2002: 200, szerzej Blok, 2018: 21-39). Dzisiaj lepiej widać, że system w pełni wolnorynkowy zaprzecza upodmiotowieniu jednostek ludzkich. Relacje pracodawca i pracobiorca mają ewidentnie charakter podmiotowo - przedmiotowy, robotnicy de facto są zniewoleni w ważnej sferze swego życia. 
Niektórzy liberalni ekonomiści, zwolennicy indywidualizmu ekonomicznego uważają, że ekonomia społeczna nie jest ścisłą ekonomią, bo kieruje się „sercem, a nie głową", bo jej uwaga koncentruje się bardziej nad opieką wobec świata pracy. Jednak oba organy muszą współdziałać, jeden nie może istnieć, funkcjonować bez drugiego. Podobnie w ekonomii. Nie mają oni racji, kierując swoją uwagę, kalkulacje wokół interesów przedsiębiorców, biznesu. Uważam, że ekonomia społeczna jest bardziej dociekliwa, stara się dookreślić optymalne interesy całego gospodarującego społeczeństwa, rozwija teorię i metodologię w znacznie szerszym zakresie. Przedstawiciele obu tych nurtów ekonomii nie mogą się jednak porozumieć. Brakuje im przysłowiowego klucza, oparcia dla stabilizacji gospodarki oraz zadowalającej teorii i metodologii.

\section{Uwarunkowania i trudności z polityką rozwoju}

Teoria ekonomii społecznej umożliwia wypracowanie realistycznej koncepcji ustroju społeczno-gospodarczego oraz polityki społecznej i gospodarczej. Proponowany ustrój to system wolnej konkurencji, wolnego rynku, częściowo kontrolowany i ogólnie planowany przez państwo. Przewagę ma w nim mieć własność prywatna, ale jest tu miejsce dla pewnego zakresu własności państwowej oraz własności spółkowej i spółdzielczej. Równowagę pomiędzy kapitałem a pracą ma zapewnić udział pracowników nie tylko we własności, lecz także w zarządzie przedsiębiorstw, i to przedsiębiorstw wszystkich kategorii własności prywatnej, spółkowej i państwowej (Wójcik 2002: 200).

Obecność państwa w życiu społeczno-gospodarczym wynika z faktu, że musi ono zastąpić inicjatywę prywatną wszędzie tam, gdzie brak jest inicjatywy i środków kapitałowych prywatnych. Dotyczy to także budowy infrastruktury gospodarczej, bankowości, kredytów, prawa, oświaty, kultury, służby zdrowia, ochrony środowiska naturalnego itp. (Wójcik 2002: 200).

W procesie decyzyjnym rola władzy państwowej nie miała polegać na narzucaniu planu społeczeństwu, lecz na współdziałaniu przy jego budowie z samorządami i przedsiębiorstwami. Utrzymanie zaś mechanizmu rynkowego miało gwarantować samodzielność w podejmowaniu decyzji podmiotom gospodarczym (przedsiębiorstwom). Ten ustrój i jego 
polityka społeczno-gospodarcza wykluczały kolektywizację rolnictwa, uznając ten rodzaj gospodarowania za mało wydajny, wręcz nierokujący rozwoju, jak i nacjonalizację przemysłu (Wójcik 2002: 200).

Ekonomia społeczna obejmowała politykę socjalną, która przechodziła znamienną ewolucję - od konieczności zapewnienia robotnikom prawa do pracy, wzrostu zarobków, pomocy socjalnej do zagwarantowania im udziału w zyskach jako współgospodarzom, a następnie także i współzarządzającym. Zmierza się tu do uwłaszczenia robotników (Wójcik 2002: 201).

Społeczna gospodarka rynkowa to teoria społeczeństwa gospodarującego o właściwościach indywidualistycznych, jak i uspołeczniających. W koncepcji tej występują wysuwane przez Kościół zasady: godność człowieka, pomocniczość, solidarność i sprawiedliwość. Ze względu na te wartości, jak i religijność człowieka wzywa do kierowania się moralnością, prawością, chce budować kapitał kulturowy, który będzie tworzyć dobry klimat ideowy wzmacniający poczucie pewności ludzkiego bytu. Odmienna antropologia liberalna odrzuca wciąż katolicki punkt widzenia. Ostry spór, jaki rozpoczął się w XIX w. i który trwa pomiędzy zwolennikami ekonomii społecznej a liberałami, rzecznikami indywidualizmu wolnorynkowego, wywołuje silny niepokój moralny. Jak pisałem wcześniej, indywidualizm ekonomiczny degraduje człowieka, niszczy chrześcijańską moralność (Wójcik 2010: 62) ${ }^{5}$. Uporczywie nie są przestrzegane takie zasady jak m.in. uczciwość we wzajemnych relacjach (przedsiębiorcy - pracobiorcy - urzędnicy), bezstronność w rozstrzyganiu sporów, poszanowanie praw stron. Akceptowane są niegodne metody zdobywania i poszerzania zysków, bogactwa, władzy. W rezultacie znika fundament współżycia i całe życie społeczne jest wystawione na ryzyko rozkładu.

5 Jak zauważa C.S. Bartnik (2019: 8): „[...] dziś Polacy jakby nie poznają samych siebie w szale nienawiści społecznej [...] Oto zaczynamy być zalewani jakimś tsunami nienawiści społecznej ze strony tak zwanego liberalizmu wdzierającego się z zewnątrz i znajdującego coraz szerszą akceptację znacznej części społeczeństwa [...] Przy tym prawie nikt nie bierze pod uwagę, że głównym złem jest w każdej sytuacji zło moralne, które obejmuje nie tylko jednostkę, ale całe społeczeństwa. Jego źródłem jest przede wszystkim ateizm. Moralność jest nie tylko poglądem, poczuciem wewnętrznym, ale jest przede wszystkim podstawowym czynnikiem życia, siłą praktyczną i decyduje o istocie człowieczeństwa [...] Ateiści niby mówią, że mają swoją etykę, ale jest to raczej zespół reguł dla własnego pożytku życiowego”. Podobnie P. Lisicki (2020: 3): „[...] żyjemy w systemie, w którym wiara i moralność klasyczna jest wypierana przez nową ideologię radykalnej emancypacji jednostki (prymat doczesności nad nieśmiertelnością duszy)”. 
Podstawę indywidualizmu stanowi darwinowska walka o byt - zysk. W pełni wolny rynek ma przesądzać o całym życiu społecznym, ale degraduje go i otwiera drogę do rozprzestrzeniania się materialistycznego i ateistycznego liberalizmu zachodniego.

Od 30 lat stoimy przed wielkim historycznym problemem wyboru drogi rozwoju opartej na kreowaniu otwartej polityki gospodarczej w łączności, czy może zależności od UE i USA, czy bardziej samodzielnie, narodowo. Obie linie rozwoju mają wśród elit politycznych i gospodarczych zwolenników i zagorzałych przeciwników. Nie bez znaczenia jest opinia społeczeństwa, które dźwiga na swych barkach koszty transformacji ustrojowej. Duża jego część przychyla się do opcji drugiej, dla której priorytety to wolność i godność narodu, i człowieka uposażonego na drodze uwłaszczenia we własność prywatną, powstanie polskiej klasy średniej i w efekcie kapitalizmu z ludzką twarzą (Wójcik 2002: 201).

Myśl liberalna od swych początków, tj. od Adama Smitha, i dalej ewoluując, zakładała, że własność prywatna, wolność gospodarcza, wolny rynek nie stanowią jeszcze o istocie kapitalizmu, że należy do niego też określony system społeczny, polityczny, prawny i moralny. W literaturze ekonomicznej z rzadka przypomina się, że instytucje te (rynek, własność, konkurencja) nie są darem natury, ale są przez ludzi wypracowane na gruncie określonego systemu społeczno-politycznego, w zgodzie z obowiązującym prawem i zasadami moralnymi. Będąc produktem tego systemu i reguł, własność prywatna oraz rynek, czyli kapitalizm - jak słusznie zauważa Kazimierz Z. Poznański - jest tym silniejszy, im solidniejsze są prawne i moralne podstawy (Poznański 2001: 14).

Początkowa dynamika kapitalizmu wyrastała niewątpliwie ze stosunkowo szerokiego zasięgu własności. Dlatego zrozumiała była liberalna krytyka systemu feudalnego, w którym kapitał (ziemia) znajdował się w ręku 2-10\% uprzywilejowanej części społeczeństwa, jak i negacja socjalizmu, w którym co prawda nie liczyła się własność, ile kontrola nad kapitałem. Jednak dalszy jej rozwój wykazał, że liberalizm nie zapobiegł rozwojowi monopoli, tym samym tworzył warunki do powstania wąskiej bazy społecznej własności, a proletariat znalazł się w sytuacji nowej eksploatacji. Z racji swej pozycji monopolisty oligarchowie kapitału znowu (jak niegdyś szlachta) przypisują robotnika do miejsca pracy i narzucają mu niekorzystną płacę.

Historia poucza nas o czterech formach ekonomicznej zależności świata pracy: feudalnej, kapitalistycznej, komunistycznej i ponowoczesnej. 
Niektórzy polscy ekonomiści, politycy, dziennikarze z wielką obawą piszą, czy obecna zmiana ustrojowa nie jest przypadkiem jeszcze inną, nową kolonizacją Polaków przez zamożniejsze europejskie narody? Co może $\mathrm{w}$ tej sytuacji istotnie niepokoić, to brak wypracowanej własnej, narodowej polityki społeczno-gospodarczej, doraźność, improwizacja.

W początkowym okresie transformacji (do 2015 r.) rządy III RP nie posiadały, nie prowadziły, uważały za zbędną narodową politykę gospodarczą. Wielu Polaków, zwłaszcza starszego pokolenia, mocno odczuwało ten brak własnej, samodzielnej koncepcji gospodarczej, jak również wielkich ekonomistów na miarę Władysława Grabskiego czy Eugeniusza Kwiatkowskiego. Szczególnie widać to było po takich zjawiskach, jak upadek rolnictwa, załamanie przemysłu, wyprzedaż banków, mediów, handlu przedsiębiorcom zagranicznym oraz towarzyszące temu bezrobocie, które narastało. Wciąż nie można obronić się przed lichwą zadłużenia międzynarodowego, nie można odrodzić klasy średniej i drobnych właścicieli, nie ma dobrze zorganizowanej ani nawet przemyślanej reprywatyzacji. A można jeszcze dorzucić prowadzone nie tylko już z ukrycia próby narzucenia społeczeństwu katolickiemu ateizmu, dążenie do rozbicia Kościoła czy rosnące bezprawie, także wśród elit politycznych i gospodarczych. Ataki na idee i prawo uwłaszczenia ostatecznie załamały wieloletnią akcję uwłaszczeniową, prowadzoną przez prof. Adama Bielę i działacza Solidarności Tomasza Wójcika. Uwłaszczenie obywateli wypływało z podstawowej polskiej racji stanu, a ataki na nią uważano za antynarodowe i antyhumanistyczne, uniemożliwiające odbudowę polskiej klasy średniej (Wójcik 2002: 204 i n.). Od zawsze problemem są podatki. Potrzebny jest $\mathrm{w}$ pełni przejrzysty system podatkowy. Znaczenie stabilizacji prawa podatkowego dla kształtowania dobrego klimatu moralnego stale podkreślał Stefan Kurowski (18.10.2003: 4; 30.08.2003: 5), ale wciąż trwają spory. Liberałowie demonizują podatki, prowadzą nawet propagandę antypodatkową, twierdząc, że są one z gruntu złe i szkodliwe, są za duże i marnowane przez państwo. Dziś widzimy, że takie stanowisko to ucieczka od odpowiedzialności za stan finansów społeczeństwa - państwa. Państwowcy usiłują precyzować politykę fiskalną, ale jak dotąd arbitralnie, w małym jeszcze stopniu uwzględniają postulaty podatników. Mało jest dyskusji wokół prowadzenia polityki pieniężnej, która pozwala odpowiednio kierować gospodarką, chodzi o umiejętne regulowanie podaży pieniądza na rynku przez zwiększanie lub zmniejszanie tej podaży w celu stabilizowania cen oraz wspierania rozwoju gospodarczego. 
Nasi antenaci wiedzieli, że mają odbudować silną gospodarkę polską, służącą obywatelom i stale poprawiać jej kondycję (Grabscy, Roman F. Rybarski, Mieczysław Młynarski i in.), prowadzić skuteczną politykę społeczno-gospodarczą, szczególnie chronić złotego, rolnictwo polskie, uobywatelnić klasę robotniczą, upodmiotowić podatkowo samorządy, oraz dążyć do uprzemysłowienia kraju (Leon Biliński, Jerzy Zdziechowski, Ignacy Czuma), a przy tym rozwijać teorię ekonomii (Adam Krzyżanowski, Adam Heydel, Edward Taylor, Ferdynand Zweig, Tadeusz Brzeski, Władysław Zawadzki). Nie obawiali się interwencjonizmu państwowego. Opowiadali się za kompetentną syntezą gospodarki rynkowej z gospodarką planową państwa. Zagadnienia te były przez nich systematycznie rozwijane (Leon W. Biegeleisen, Edward Lipiński). Pomagała tu krytyka etatyzmu prowadzona przez nurt liberalny, wykazująca, że etatyzm powoduje spadek oszczędności produkcyjnych, przyczynia się do rozwoju monopolu przedsiębiorstw państwowych, ostrzegając, że jest stadium przejściowym na drodze do socjalizmu. Przestrzegali przed ustrojem socjalistycznym jako gospodarczo niewydolnym, przed upaństwowieniem całej gospodarki narodowej, przed biernością społeczeństwa, stąd się wywodzącą, a zarazem przed rozrostem zjawiska biurokracji. Podkreślali konieczność realizowania w Polsce zasady sprawiedliwości społecznej, humanizowania kapitalizmu (Heydel, A. Doboszyński). Obaj Grabscy, przed Keynesem, popierali inflacyjne zwiększenie inwestycji (robót publicznych) $w$ celu powiększenia siły nabywczej społeczeństwa (jako szybkiej ucieczki z kryzysu gospodarczego), jak i dania zatrudnienia całemu przyrostowi naturalnemu ludzi wchodzących w wiek produkcyjny (ok. 300 tys.). Przyszłość gospodarczą Polski łączyli już wtedy z wprowadzaniem naszego kraju do grupy państw aktywnego kapitalizmu (Zofia Daszyńska-Golińska). Podkreślali przy tym, że ten proces modernizacyjny należy realizować własnymi siłami elit wespół ze społeczeństwem (Wójcik 2002: 213).

Dzisiaj bardzo ważne są pytania o cele i zadania, jakie UE stawia sobie i państwom, które dołączyły do niej w XXI w., czy Polska będzie nadal odnosić korzyści z faktu członkostwa? Są one widoczne w sferze finansowo-gospodarczej. Ale stale trzeba obserwować, czy nie płacimy zbyt wysokiej ceny. Chodzi o to, by nasza gospodarka nie stała się w gruncie rzeczy peryferyjną, niezdolną do konkurencji w świecie. Już obecnie dynamika niektórych sektorów gospodarki, np. przewozy, są blokowane przez decyzje UE. Ponadto Komisja Europejska coraz bardziej opresyjnie ingeruje 
w nasze życie społeczno-obyczajowe, religijne oraz prawne, np. chce uzależnić dotacje od jakiejś ogólnej praworządności. W sumie, czy ten obezwładniający nacisk rządów partii liberalno-lewicowych UE, usiłujących zmarginalizować rządy partii konserwatywnych (Polska, Węgry), może uniemożliwić Polsce wybicie się na równoprawne partnerstwo w przyszłości. Dlatego na władzach państwa ciąży obowiązek przygotowania Polski do samodzielności gospodarczej, politycznej i kulturowej opartej na personalistycznej ekonomii społecznej.

W europejskiej myśli społeczno-ekonomicznej trwale współwystępuje szereg doniosłych zagadnień, do których odnoszą się wciąż główne systemy teoriopoznawcze i ideowe, takie jak liberalizm, socjalizm, marksizm, ordoliberalizm, keynesizm, monetaryzm, teoria ludowego kapitalizmu, katolicka nauka społeczna, a także są obecne w rozlicznych wystąpieniach polityków, w publicystyce i dyskusjach prywatnych. Są to takie tematy jak: ustrój państwa, model gospodarki, wolność jednostki, postęp cywilizacyjny, problem sprawiedliwego rozdziału dóbr. Z tym ostatnim łączyły się szczegółowe kwestie społeczne, jak np. cała kwestia robotnicza, partycypacja, reforma rolna, reforma oświaty, służby zdrowia, systemu podatkowego i ubezpieczeń, samorządowa oraz kontrowersyjna koncepcja uwłaszczenia społeczeństwa w Polsce. Szczególnie to ostatnie zagadnienie żywo obchodziło parlamentarzystów, naukowców, a także społeczeństwo polskie. Była próba politycznego i ustawowego rozwiązania problemu uwłaszczenia, która jednak została stłumiona przez weto prezydenta i postawę części polskiego parlamentu, lecz uważam, że ten kluczowy temat, podobnie jak i inne prawdziwe wielkie tematy myśli społeczno-ekonomicznej nie znajdują na dłużej definitywnych rozstrzygnięć, tak w praktyce, jak i w teorii, oraz będą na nowo podejmowane i przeżywane, po prostu nie dają się na dłużej unieważnić (Wójcik 2002: 214).

Poszukiwanie przyczyn niesprawiedliwości społecznej, jak i możliwości zespolenia wolności gospodarowania ze sprawiedliwością zrodziło różne odmiany socjalizmu, marksizm, keynesizm. Zagadnienia te podjęła również katolicka nauka społeczna.

Dzisiaj wiemy już, że tak naprawdę bezpieczeństwo i godność człowieka poszukiwane przez Karola Marksa w socjalizmie nie było trafne. Marks popełnił szereg błędów w swej teorii ekonomii (zawartej w Kapitale), z których jeden warto tu podkreślić: nie był on w stanie zrozumieć, że prywatne posiadanie własności ze środkami produkcji włącznie jest nierozerwalnie związane z wolnością polityczną. Można uznać, że wykazał 
brak zrozumienia, iż państwowa własność środków produkcji jest zagrożeniem ludzkiej wolności.

Podzielam częściowo przekonanie Luisa O. Kelso, który odpowiadając na zarzut, że własność kapitału ma tendencję do zbytniej koncentracji, stwierdził, iż przeciwdziałanie dyktatowi kapitału i wyzyskowi leży we właściwym ustawodawstwie i prawidłowym używaniu rządowych regulacji, mających na celu kontrolę procesu koncentracji, sprzyjaniu powstawania własności prywatnej. Korzyści, jak i sukcesy kapitalizmu rosną proporcjonalnie do liczby ludzi będących kapitalistami. Natomiast bogactwo nowych oligarchów nie przekłada się na bogactwo świata pracy (Wójcik 2002: 215).

Nowy kierunek naprawczy zasugerował ostatnio raport CEED Institute, wskazując, że państwo powinno regulować, wyznaczać reguły konkurencji i gwarantować ich przestrzeganie, ale nie może planować i sterować procesem ekonomicznym. Formy konkurencji mają być legalne i uczciwe, ale mimo to rynki nadal przyciągają nie tylko przyzwoitych ludzi. Jeśli więc pozostawi się je zupełnie wolnymi, to niektóre jednostki i grupy będą naginać zasady, a ich chciwość niszczyć rynek. Ponadto państwo winno zajmować się obronnością, wymiarem sprawiedliwości, infrastrukturą techniczną i społeczną (edukacją, ubezpieczeniami i in.) oraz dziedzinami strategicznymi. Raport zwrócił uwagę na kluczową kwestię podejmowania decyzji w gospodarce, dotąd ujmowaną zbyt jednostronnie. Autorzy raportu uznali, że zdominowanie decyzji przez potężne grupy gospodarcze i finansowe stanowi lustrzane odbicie równie szkodliwych decyzji podejmowanych przez głównych polityków państwa (rządu) niegwarantujące procesu zrównoważonego rozwoju społeczno-gospodarczego. Jednak pozostawili tę kwestię otwartą, nie do przyjęcia w dłuższej perspektywie dla sprawiedliwego, efektywnego i stabilnego funkcjonowania demokratycznego państwa prawa oraz społecznej gospodarki rynkowej (cyt. za Kohler 16-17.01.2015). Ekonomiści, politycy, publicyści z niepokojem piszą o utrzymujących się nieprawidłowościach, o błędnych decyzjach, lukach $\mathrm{w}$ prawie, nepotyzmie i co staje się bardzo groźne, utrzymywaniu się tzw. grup trzymających władzę (sieciowych relacjach polityków i oligarchów). Wtedy to oni będą decydować, kto będzie miał wstęp na rynek, tworzyć prawo, które pozoruje legalność. Politykom liberalno-lewicowym w Polsce zarzuca się brak posiadania pozytywnego programu rozwoju gospodarczego, a ostatnio, że mają oni wprawdzie plan, ale negatywny, pełen frazesów o bogaceniu się społeczeństwa polskiego, o wspieraniu 
przepływów własności prywatnej (jednak nie mówi się wyraźnie od kogo do kogo, co sugeruje niejasne relacje oligarchów krajowych i zagranicznych, może dalszą wyprzedaż majątku narodowego), a przy tym chcą likwidacji polityki socjalnej, ograniczenia budżetu państwa, tj. de facto jego kompetencji i sprawności. Trudno oprzeć się wrażeniu, że brakuje tu rozumienia, co jest polską racją stanu. Przecież to jest droga do zbiednienia społeczeństwa i utrzymania gospodarki polskiej w zależności od kapitałów i państw obcych.

Droga do zbudowania nowoczesnej, konkurencyjnej gospodarki polskiej i przede wszystkim odbudowa morale społeczeństwa gospodarującego jest trudna. Wymaga od wszystkich, od rządu, ludzi nauki i biznesu, świata pracy kompetentnych, trafnych decyzji, szczególnie tych długofalowych. Widzimy obecnie, jak dynamicznie powstają w Polsce wielkie multikoncerny państwowe (m.in. miedziowy, energetyczny, chemiczny), których konieczność uzasadnia się potencjałem biznesowym skarbu państwa niezbędnym dla dalszego rozwoju gospodarki krajowej, jak i w relacji do państw aktywnego kapitalizmu. Jej powodzenie będzie zależne, czy odmieni, poprawi materialną i moralną kondycję człowieka oraz społeczeństwa w państwie.

\section{Konflikty między pracodawcami a pracobiorcami}

Żyjemy w czasach osłabienia podmiotowości państwa i nie mamy gotowego modelu, jakie ono powinno być. Według czołowych liberałów polskich „odgrzewających” stary pogląd - nieprzystający do Polski wskutek jej położenia geopolitycznego - instytucja państwa jest wrogiem wolności, ponieważ stosuje przymus, zniewala, nie liczy się z jednostką i jej światem. Z kolei postkomuniści widzą w państwie tzw. oświecone centrum, omnipotencję kontrolującą wszystko i wszystkich. I jedni, i drudzy mówią przy tym, że należy zapomnieć o państwie opiekuńczym i sprawiedliwym. W rezultacie bardzo mało, prawie nic, nie pisze się o państwie jako instytucji pomocniczej, koncepcji formowanej na gruncie katolickiej nauki społecznej oraz personalizmu systemowego. Główny problem to: czy mamy stawiać na prywatyzację bez „dobra wspólnego”. W początkowym okresie transformacji (do 2015 r.) likwidowano majątek państwa, powstawały monopole własności grupowej i jednostkowej (przed którymi tak 
bardzo przestrzegał Smith). Do rangi ideału została wyniesiona absolutna prywatyzacja, w efekcie przestano pisać o dobru wspólnym dla wszystkich obywateli. Także wolny rynek, jak się wydaje - patrząc na dzisiejszą rzeczywistość - jest wolny od wszelkich norm społecznych, prawnych i moralnych (co znowu jest w niezgodzie z poglądami Smitha, który dowodził, że gospodarka rynkowa wnosi postęp społeczny i moralny, a nie tylko ekonomiczny). Sytuacja dzisiejsza przypomina obaloną przez życie tezę marksistowską, że ekonomia jest bazą i regulatorem wszystkich dziedzin życia, jest to wciąż wąski ekonomizm, nieprzystający do żadnej antropologii klasycznej ${ }^{6}$.

W tych warunkach pracodawca i robotnik stają się wrogami, chociaż wydawało się, że po historycznych doświadczeniach wyciągnięto właściwe wnioski. Okazuje się, że jednak nie. Przyznają to sami ideologowie zachodni, którzy bez ogródek stwierdzają, że mała własność dla zwykłych robotników jest tylko źródłem ich deprawacji, rozleniwienia, przestępczości, że związki zawodowe są niepotrzebne, ponieważ krępują śmiałe inicjatywy menedżerów, hamują rozwój gospodarczy, szerzą nieprawdziwe poglądy o równości społecznej, że w ogóle świat robotniczy i chłopski jest prymitywny i rozpuszczony przez dawne ideologie i powinien być wychowywany przez ciężką pracę, bezrobocie, niedopuszczony do wyższego wykształcenia i stanowisk, skąd, jak sądzę, brała się liberalna antykulturalna polityka władz, przyznawania coraz mniejszych sum z budżetu na rozwój oświaty, służby zdrowia, kultury. Warto ponownie przytoczyć wciąż aktualną opinię Bartnika wyjaśniającą jej cele i konsekwencje: „Masy pracownicze, których nie da się zagospodarować, winny wymierać - stąd aborcja, eutanazja, osłabienie służby zdrowia, szerzenie plag wyniszczających ludność. Tymczasem masy te są zabawiane obrazkami TV, pornografią, sportem, powszechną prostytucją żeńską i męską, konfliktami wewnątrzrodzinnymi, uzależnieniami, loteriami, niekaranymi rozbojami, terroryzmem, obchodami rocznic i świąt, folklorem, nic niedającymi głosowaniami, obietnicami na przyszłość i opowiadaniami bajek o raju europejskim" (Bartnik 30.04.2002; Z. Blok 2018, s. 30). Tak oto załamuje się godność człowieka, wspólnoty. Ma miejsce faktyczne kolonizowanie pracobiorców przez narzucanie im płac śmieciowych, odbieranie

6 Doktryna liberalna wnosi wiele rozwiązań pożytecznych, z różnych punktów odniesień jest ona rozpatrywana w niniejszym studium, ale chodzi o jej dzisiejszą ewolucję po Maastricht I i II. Jej duch ogólny jest jakiś drapieżny, antychrześcijański i kolonizatorski. 
podmiotowości i podporządkowanie nowej liberalnej nomenklaturze. Towarzyszy temu wiara liberałów w moc w dużym stopniu patologicznego prawa, które stanowione przez elity ekonomiczno-polityczne, jako drugi filar rynku, ma zastąpić struktury państwa, autorytety, a nawet Kościół.

Hałaśliwa propaganda liberalizmu, która usiłuje zagospodarować społeczny teren dla siebie, gubi z pola widzenia odpowiedzialność - godność człowieka, całego społeczeństwa. Dlatego ten chaotyczny dzisiaj etap rozwoju liberalizmu należy poddać korekcie przez uwzględnienie etyczno-prawnego punktu widzenia, dzięki któremu będziemy wpływać na zhumanizowanie życia gospodarczego, wypychać mentalność egoizmu i brutalności.

\section{Potrzeba kontynuacji personalistycznej ekonomii}

Ekonomia, gospodarka należą do szczególnie wrażliwych obszarów działalności człowieka i społeczeństwa, które wymagają połączenia racjonalizmu z etyką. Tym oparciem, przysłowiowym kluczem do prawdziwego odrodzenia materialnego i duchowego życia w Polsce, może stać się personalizm systemowy. Problem jest trudny, bo chaos działań trwa i nie jest opanowany. Przede wszystkim opozycja polityczna, gospodarcza, jak i czynniki decyzyjne albo nie wyjaśniają podstaw, na których się opierają, albo nie widzą takich podstaw i działają ad hoc. Moim zdaniem wielką pomocą może stać się zdecydowane odniesienie do personalizmu systemowego i moralności ogólnoludzkiej. Jako społeczeństwo powinniśmy orientować całe życie społeczne, ekonomiczne, polityczne, prawne i kulturowe ku osobie ludzkiej jako najwyższej wartości określającej te wszystkie dziedziny. Ale nie ma to być indywidualizm, gdyż osoba ludzka jest $\mathrm{w}$ pełni osobą jedynie przez relację do drugiego człowieka, do społeczności i narodu. W pewnym sensie zatem również społeczność ma charakter personalistyczny. Stąd wychodzi personalistyczny paralelizm, a mianowicie osoba indywidualna wyraża się przez quasi-osobę społeczną, a społeczność tłumaczy się przez osobę indywidualną. Rozdzielenie tych dwu sfer jest ogromnym błędem tak kolektywistycznego marksizmu, jak i indywidualistycznego liberalizmu. Oba te ujęcia są jednostronne i karykaturalne. Oddzielanie życia ekonomicznego, politycznego, prawnego i kulturalnego od wielkości osoby ludzkiej i osobowości społecznej jest 
wielkim błędem, który panuje w obu dotychczasowych teoriach. Powinniśmy się więc nastawić na budowanie wyższej kultury, ponieważ ona jest poważnie zniszczona. Przy tym nie mamy klasy politycznej, ekonomicznej w znaczeniu elit mocnych. Nadal obserwuje się dużą uległość wobec utopijnych prądów zachodnich, jak kiedyś wschodnich. Oczywiście Zachód wnosi wiele technologicznie i ekonomicznie, ale nie ma nowej szlachetnej ideologii (Bartnik 2006: 48 i n., 59-60, 141-142; Wójcik 2020: 18-22). Dlatego sądzę, że wszyscy musimy dążyć do oparcia ekonomii, całego życia społecznego na personalizmie systemowym i zmierzać do kierowania tymi procesami, które muszą być związane, wyrastać z naszej rzeczywistości.

Teoretycy i publicyści piszący o demokratycznym państwie prawa, jakim jest III RP, inspiracje w określeniu jej roli i celów znajdywali w liberalizmie, neomarksizmie, nowej lewicy, a także w katolickiej nauce społecznej. Mamy więc konglomerat idei niespójnych, eklektyzm. Szczególną uwagę pragnę zwrócić na personalizm europejski i polski w duchu Strzeszewskiego, Bartnika i przede wszystkim papieża Jana Pawła II i prymasa Stefana Wyszyńskiego. Myśl chrześcijańsko-społeczna bazuje na podstawowych zasadach społecznych: godności osoby ludzkiej, dobra wspólnego, pomocniczości, sprawiedliwości, solidarności i prawdzie. Mają one pewne zastosowanie. Ich wpływ znalazł odbicie w obecnie obowiązującej konstytucji, która do tych zasad nawiązuje. Jednak politycy różnych orientacji posługują się nimi wciąż czysto wybiórczo. Należy tę sytuację odmienić. Myśl chrześcijańsko-społeczna od lat 70. XIX w. posiadała całkiem nową filozofię władzy politycznej i życia społeczno-gospodarczego: głosiła władzę jako praworządną służbę, wzywała do demokratyzacji, humanizacji i personalizacji. Rozwinęła się ona w personalizm społeczny, który jak najbardziej nadaje się do wykorzystania współcześnie. Tymczasem wciąż trudno jest wdrażać zasady moralne, a nawet normy prawa, a także oceniać skutki bo politycy odmiennych orientacji ideowo-politycznych patrzą na społeczeństwo z różnych punktów widzenia, m.in. partyjnego, doktrynalnego. Chodzi o problem celów, przede wszystkim o konkretną teorię społeczną, gospodarczą, polityczną i prawną. Wszystkie wywody o tych problemach bez spójnych założeń i zasad nie mają wartości ani poznawczej, ani pragmatycznej. Przeszkodą jest i to, że nie jest wyraźnie zakreślony obecny ustrój państwa, jesteśmy między kapitalizmem a socjalizmem, państwo jest kwestionowane, czy ma być rządzącym nadzorcą, arbitrem, rodzajem gospodarstwa społecznego, filią partii czy tylko urzędem? (Wójcik 2018a: 9). 
Może być i tak, że eurokonstytucja właściwie pozbawi państwa członkowskie ścisłej państwowości, chcąc stworzyć jedno państwo europejskie, albo że UE będzie miała dwóch hegemonów (Niemcy - Francja). W takiej sytuacji podstawowe funkcje przejmie Bruksela, a nasze państwo może stać się regionem, przez to i teorie nie będą obowiązujące, a nasze dyskusje niewiele dadzą. Jeśli konstytucja unijna wejdzie $\mathrm{w}$ życie to teorie będą dyktowane przez intelektualne zaplecze Brukseli, a nie przez nas (Wójcik 2018a: 10).

Wielu młodych i starszych Polaków odczuwa brak perspektyw życia. Pośród oligarchów i notabli występuje korupcja na wielką skalę, odnotowuje się olbrzymie zadłużenie wewnętrzne i zewnętrzne. Ponadto nie jest przestrzegana konstytucja, obserwuje się chaos prawodawczy, niewydolność służb prawniczych i całkowity upadek zasad publicznych. Społeczeństwo, część polityków, prawników i politologów w Polsce bije na alarm, że państwo i prawo funkcjonują źle, powszechnie zaś uważa się, że obecne sejmy na ogół stanowią złe prawo, a przecież III RP miała stawać się demokratycznym państwem prawa. Warto w tym miejscu przypomnieć krytyczne stanowisko Bartnika w odniesieniu do oceny obowiązującego w Polsce prawa. Zauważa on, że w formule „państwo prawa" nie dostrzega się znaczenia osoby ludzkiej. O człowieku mówi się tylko jako o jednostce $\mathrm{w}$ istocie konsumpcyjnej, którego jedynym celem jest przyjemność i korzyści. Aspekt moralny nie ma tu żadnego znaczenia, jego rolę ma spełniać wyłącznie norma prawna, a decydentem życia zbiorowego jest polityk, urzędnik. Samo prawo nie oddaje istoty i głębi człowieka jako osoby (Bartnik 2008: 425). Normatywizm prawny uznaje za błędny, formalistyczny.

Podzielam przekonanie, że prawo winno być uwarunkowane całą osobą ludzką. Jego źródłem jest równa godność przysługująca każdemu człowiekowi. Sam legalizm prawny jest tylko okazją do nadużyć, co pokazuje obecna sytuacja w Polsce. $W$ personalizmie systemowym podstawowe są prawa bytu i istnienia, stąd wynikają normy etyczne i całość rozgrywa się w świecie osoby, która kieruje się sumieniem i prawem jednocześnie. Nie oznacza to, że prawo jest mniej ważne, ale nie może funkcjonować wbrew etyce, bez godności całej osoby ludzkiej. Doświadczenie współczesne mówi, że nie wystarcza sama instytucja państwa wyznaczająca i pilnująca reguł konkurencji i gwarantująca ich wykonanie, że zbyt mało znaczy odcięcie państwa od sterowania procesem gospodarczym. Wiedzieli już o tym europejscy myśliciele chrześcijańscy domagający się 
pogłębienia etyki katolickiej. W obecnym procesie modernizacji politycy, prawnicy, ekonomiści, politolodzy oraz samorządowcy nie docenili należycie potrzeby przebudowy instytucjonalnej państwa. Zwłaszcza politycy opozycyjni nie rozumieją znaczenia logiki instytucjonalnej. W rezultacie koncentrując się na sprawach gospodarczych, zdeformowali państwo, nie wprowadzając nowoczesnych, jakościowych metod zarządzania, kompetentnie realizujących tzw. polityki szczegółowe. A przecież ustrój społecznej gospodarki rynkowej jest zapisany w konstytucji (art. 20), która wzywa kolejne rządy, aby dbały o ład gospodarczy respektujący poczucie godności człowieka.

Personalizm systemowy to nurt filozoficzny, według którego osoba jest źródłem, podmiotem i celem dynamicznej rzeczywistości społecznej, a także kategorią poznania oraz działania i tworzenia. W przeciwieństwie do idealizmu i formalizmu jest to personalizm realistyczny, uniwersalistyczny. Personalizm uznaje zasadę godności osoby ludzkiej, tzn. że należy ją szanować, afirmować dla niej samej. Człowiek jako osoba w życiu publicznym ma pierwszeństwo i autonomię. Godność osoby ludzkiej domaga się budowy życia społecznego, rozwijania wspólnoty opartej na zasadach dobra wspólnego, solidarności, sprawiedliwości i pomocniczości. Porządkują one system społeczny (polityczny, gospodarczy) na miarę człowieka jako osoby, umożliwiają stworzenie takich struktur, w których osoba ma zapewnione poszanowanie swej godności i posiada szansę pełnego, integralnego rozwoju (Wójcik 2018b: 717; 2020: 30).

Jaki ma być status jednostki w państwie, według personalizmu - jej sfera wolności? Warto przypomnieć tę jakże ważną kwestię dzisiaj, ponieważ w czasach, w których żyjemy, dominacji liberalizmu, socjalizmu, wielu gubi się w rozumieniu ludzkiej natury. Przez wieki wolność (łac. liberalis - wolny) oznaczała niezależność od przymusu społecznego, utrzymywania jednostek w bardzo silnej zależności. Jednostki i ruchy społeczne usiłowały go przezwyciężać, odwołując się do idei samowystarczalnej osoby, dla której wszelkie naturalne więzi, tożsamość (rodzinna, narodowa, kulturowa, religijna) były tylko ograniczeniami, a nie naturalnym środowiskiem rozwoju. Widać to było dobrze w procesie ewolucji i rewolucji formacji feudalnej w liberalny system kapitalistyczny. Miał on długo dobre znaczenie. Działo się tak, ponieważ rozwijał się w kulturze chrześcijańskiej, w jej wyobrażeniu osoby ludzkiej i jej godności. Jednak doświadczenia wojen religijnych zrodziły hasła mówiące o wycofaniu religii do sfery prywatnej i o neutralności państwa. Ta ostatnia początkowo 
nie znaczyła, że dystansuje się ono od etyki, a hasło przesunięcia religii do sfery prywatnej nie miało prowadzić do jej eliminacji z życia publicznego. Jednakże rozwijanie liberalizmu doprowadziło do stanu obecnego. Zauważano jednak (A. de Tocqueville, E. Durkheim, M. Weber) zagrożenia wyrastające $\mathrm{z}$ upadku autorytetu religii i tradycji dla spoistości trwania demokratycznego społeczeństwa. $W$ okresie rozwoju neoliberalizmu wolność została rozciągnięta na wszystko - od etyki, kultury, prawa oraz Boga, aż do wolności tworzenia zła, np. wolność mówienia nieprawdy, odwracanie pojęć, ukrywanie rzeczywistości, co uniemożliwia zrozumienie świata i siebie nawzajem. Personalizm nie ogranicza wolności, gdy stwierdza, że ma być twórcza, odpowiedzialna i sprzyjająca rozwojowi poczucia godności człowieka (Wójcik 2018b: 720).

Celem i ośrodkiem życia społeczeństwa ma być osoba ludzka. Nie wolno odrywać życia społeczno-ekonomicznego od człowieka - osoby, nadawać mu charakteru mechanicznego. Osoba ludzka, jej potrzeby i uzdolnienia winna stanowić ośrodek życia publicznego, a jej dobro - cel tego życia. Przez człowieka następuje związek władzy z moralnością i religią. Personalizm przyznaje jednostce ludzkiej nieporównanie większe znaczenie niż marksiści i liberałowie w zakresie kształtowania struktur społeczeństwa i swojego rozwoju. Skąd bierze się tak silne eksponowanie godności i dobra każdej osoby w personalizmie? Otóż, jak wynika z historii, jak i z naszych czasów (III RP), mimo obietnic wielu pokoleń polityków oraz ideologów socjalistycznych i liberalnych, że będzie lepiej, większość społeczeństwa wciąż nie radzi sobie z trudnościami zmieniającej się rzeczywistości. Za każdym razem, kiedy lud upominał się o swoje interesy i godność, spotykał się z oskarżeniami kolejnych elit o bycie hamulcowym przemian, że okazał się niereformowalny, że jest zbędny.

Wyjaśnienie natury oraz celu życia człowieka i społeczeństwa, jakie udziela personalizm, wyprowadza z określonych uwarunkowań historycznych, politycznych, gospodarczych, kulturowych i religijnych Polski mających silne związki z klasyczną, europejską myślą filozoficzną w kształtowaniu wyobrażeń intelektualnych na temat ekonomii, polityki, kultury. Uważa się, że odrębność cywilizacyjna oznacza obowiązywanie odmiennych zasad organizacji społeczeństwa. Z tego punktu widzenia przekonania rządzące postępowaniem czy uzasadniające porządek prawny są różne w różnych kulturach. Dla personalistów konieczne jest zwrócenie uwagi na typ cywilizacji, z której polityka i gospodarka wypływa, a która ustala dla niej główne doktrynalne punkty odniesienia. 
Usytuowanie polskiego narodu i państwa w obrębie religii i kultury łacińskiej kształtowało racjonalny, a zarazem atrakcyjny sposób życia społecznego przez to, iż podporządkowywały one człowiekowi różnorodne formy instytucjonalne w państwie. Niewątpliwie to dla człowieka konieczna okazuje się cała infrastruktura społeczno-gospodarcza. Państwo winno współtworzyć warunki dla rozwoju aktywności, wolności i podmiotowości człowieka oraz prawdziwej wspólnoty. Stawia to osobę na szczycie wartości politycznych, ekonomicznych i kulturowych, rozwija u ludzi poczucie godności, szacunek i autorytet. Takie podejście kultywuje polską republikańską tradycję. Personalizm precyzuje zakresy podmiotowości człowieka, rodziny, społeczeństwa i państwa. Poszerza zakres przedmiotowy ekonomii o etykę, pełną, prawdziwą historię, w integracji z Europą. W refleksji tej uznaje się człowieka jako osobę, tj. świadomy i wolny podmiot działania oraz podmiot praw - podkreśla się godność osoby ludzkiej. Takie ujęcie roli człowieka wpływa pozytywnie na jego kondycję psychiczną, motywuje do działania silniej niż egoizm, będzie kształtować etyczną, silniejszą niż kiedykolwiek klasę średnią. Człowiek jako osoba posiada wymiar społeczny, co oznacza, że do swego istnienia i rozwoju potrzebuje społeczności. Jest bytem korelatywnym w stosunku do innych osób. Ta osobowa natura człowieka wyjaśnia istnienie, a także nieustannie poszukuje lepszych form funkcjonowania społeczeństwa gospodarującego. Celem ich działania powinien być człowiek, jego rozwój w ramach harmonijnych stosunków społecznych (Wójcik 2018b: 725). Stoimy przed potrzebą dokonania zasadniczej korekty w patrzeniu na człowieka w duchu personalizmu społeczno-ekonomicznego.

\section{Zakończenie}

Przeważające obecnie nurty w ekonomii (liberalizm, neoliberalizm) zdają się istnieć daleko od podstawowych wartości osobowych, np. etyki. W ekonomii, podobnie jak i w polityce moralność po prostu przestaje istnieć. Jest to wielkie zadanie stojące przed tą nauką. Musimy ją personalizować, wyeliminować mentalność egoizmu, obłudy i brutalności (Wójcik 2018a: 194). Jestem przekonany, że bez zastosowania i rozwoju systemu personalistycznego nie zhumanizujemy życia publicznego i pozostaniemy rozdarci między ideą personalistyczną a dominującym światem 
indywidualizmu. Jak dotychczas, człowiek jako osoba funkcjonuje bardzo słabo na płaszczyźnie życia ekonomicznego.

Z uwagi na skalę obecnego kryzysu życia społeczno-gospodarczego i polityczno-kulturowego, w którym z jednej strony człowiek chce się na nowo poznać, zrozumieć i uwolnić, ale z drugiej jakby traci zmysł samozachowawczy - zabija siebie, łamie dekalog życia, a także degraduje się, ośmiesza swoją godność, szlachetność, uważam, że z niego może nas wyprowadzić personalizm wzywający do przywrócenia godności osobie ludzkiej, bo jest ona podstawą życia społeczności. Człowiek to nie towar, konsument bez balastu wartości, tak jak widzi go liberalizm. Pełny człowiek ma swoje interesy i ukształtowany system wartości, gdzie godność osoby ludzkiej, jej wolność, dobro wspólne, solidarność, sprawiedliwość, życie w prawdzie zajmują centralne miejsce. Dobrze funkcjonującą gospodarkę rynkową stanowiącą wartość dla jednostki i społeczeństwa można utrzymać na podstawie tych obiektywnych i niezmiennych wartości.

\section{Bibliografia}

Bartnik, C. S. (2001), Osoba i historia. Szkice z historii filozofii, (Lublin: Starodruk). Bartnik, C. S. (30.04.2020), Grzech pierworodny III Rzeczypospolitej, „Nasza Polska”. Bartnik, C. S. (2006), Szkice do systemu personalizmu, (Lublin: Wydawnictwo KUL). Bartnik, C. S. (2013), Personalizm, (Lublin: Wydawnictwo KUL).

Bartnik, C. S. (1-2.06.2019), Potrzeba ludzi sumienia, „Magazyn. Nasz Dziennik”.

Beksiak, J. (1976), Społeczeństwo gospodarujące, wyd. 2, (Warszawa: Państwowe Wydawnictwo Naukowe).

Blok, Z. (2018), Niedefiniowalne modeli państw liberalno-demokratycznych. [w:] W. Bulira, Granice teorii polityki. Świat zachodni w stanie zagrożenia, (Lublin: Wydawnictwo Uniwersytet Marii Curie-Skłodowskiej).

Gacka, B. (2012), Personalizm w ekonomii, (Warszawa: Stowarzyszenie EkosystEM - Dziedzictwo Natury).

Haring, B. (1968), Personalismus in Philosophie und Theologie, (München: Erich Wewel). Jaroszyński, P. (2006), Człowiek i państwo. Przyszłość cywilizacji Zachodu, (Lublin:

Fundacja: „Lubelska Szkoła Filozofii Chrześcijańskiej”).

Kohler, H. (16-17.01.2015), Rola państwa w gospodarce, „Rzeczpospolita”: 19.

Koneczny, F. (1996), O wielości cywilizacji, (Kraków: Wydawnictwo WAM).

Korab, K. (2005), Wtadystaw Grabski i jego wizja świata społecznego, [w:] J. Konefał, S. Wójcik (red.), Wtadystaw Grabski. Uczony i maż stanu, (Lublin: TN KUL): 41-43. 
Kornai, J. (1977), Anti - Equilibrium. Teoria systemów gospodarczych. Kierunki badań, (Warszawa: Państwowe Wydawnictwo Naukowe).

Kowalczyk, S. (1990), Zarys filozofii człowieka, (Sandomierz: Wydawnictwo Diecezjalne).

Krąpiec, M. A. (1986), Człowiek i prawo naturalne, (Lublin: TN KUL).

Kurowski, S. (18.10.2003), Budżet katastrofy. Od schładzania Balcerowicza do cięć Hausnera, "Głos": 4.

Kurowski, S. (30.08.2003) Skończyć z polityka niedoboru pieniądza, "Głos”: 5.

Lisicki, P. (21-28.12.2020), Proroctwa dla Zachodu, „Do Rzeczy”, nr 52: 3.

Maritain, J. (1950), Persona e società, Gallarate.

Maritain, J. (1988), Pisma filozoficzne, (Kraków: Znak).

Mounier, E. (1964), Co to jest personalizm, (Kraków: Znak).

Poznański, K. Z. (2001), Obłęd reform. Wyprzedaż Polski, (Warszawa: Ludowa Spółdzielnia Wydawnicza): 14

Raport Central and Eastern Europe Development Institute (CEED).

Smolka, B. (2002), Narodziny i rozwój personalizmu, (Opole: Redakcja Wydawnictw Wydziału Teologicznego UO).

Sobczak, J. (2002), Zmierzch cywilizacji, (Poznań: Wydawnictwo Naukowe INPiD UAM).

Strzeszewski, Cz. (1967), Życie ekonomiczno-społeczne i polityczne wspólnoty ludzkiej, "Zeszyty Naukowe KUL" 2: 17-23.

Strzeszewski, Cz. (1994), Katolicka nauka społeczna, (Lublin: Redakcja Wydawnictw KUL).

Whitman, W. (1994), Demokracja i personalizm, oprac. B.B. Gacka, (Lublin: „Intrograf”). Wojtyła, K. (1977), Osoba, podmiot i wspólnota, „Roczniki Filozoficzne” 24(2): 6-39.

Wójcik. S. (1995), Ekonomia społeczna według koncepcji Stanistawa Grabskiego, (Lublin: Wydawnictwo UMCS).

Wójcik, S. (2002), Zapomniana polska ekonomia społeczna XX w., (Lublin: Towarzystwo Naukowe KUL).

Wójcik, S. (2010), Imperialne państwo rynkowe. Dynamika i bariery, (Lublin: Wydawnictwo KUL).

Wójcik, S. (2015) Personalizm polityczny. Zarys problemów, (Lublin: Wydawnictwo KUL).

Wójcik, S. (2018a), Polskie drogi personalizmu społeczno-politycznego, (Lublin: Wydawnictwo KUL).

Wójcik, S. (2018b), Państwo w ujęciu personalizmu, [w:] A. Stelmach, T.R. Szymczyński, M. Walkowski (red.), Stosunki międzynarodowe w procesie zmian. Ksiegga Jubileuszowa dedykowana Profesorowi Zdzisławowi W. Puśleckiemu, (Poznań: Wydawnictwo Naukowe WNPiD UAM): 717.

Wójcik, S. (2020), Personalistyczna myśl polityczna. Wybrane zagadnienia, (Lublin: Wydawnictwo KUL). 
